\title{
CORRIGENDUM
}

\section{Human balanced translocation and mouse gene inactivation implicate Basonuclin 2 in distal urethral development}

Elizabeth J Bhoj, Purita Ramos, Linda A Baker, Vidu Garg, Nicholas Cost, Agneta Nordenskjöld, Frederick F Elder, Steven B Bleyl, Neil E Bowles, Cammon B Arrington, Brigitte Delhomme, Amandine Vanhoutteghem, Philippe Djian and Andrew R Zinn

European Journal of Human Genetics (2012) 20, 249; doi:10.1038/ejhg.2011.137

Correction to: European Journal of Human Genetics advance online The authors would like to apologise for this omission. publication, 2 February 2011; doi:10.1038/ejhg.2010.245

Dr Vidu Garg was omitted from the authors list on publication and has now been included here. 